\title{
Modifications of microcrystalline cellulose (MCC), nanofibrillated cellulose (NFC), and nanocrystalline cellulose (NCC) for antimicrobial and wound healing applications
}

https://doi.org/10.1515/epoly-2019-0013

Received August 16, 2018; accepted September 10, 2018.

\begin{abstract}
Recently, great attention has been paid to nanocomposites of cellulose, due to their unique structure as a most abundant natural polymer with having exceptional properties such as renewable, biodegradable and high specific tensile strength, aspect ratio, and Young's modulus. Prominent cellulose is naturally present in plant lignocellulosic biomass as a biocomposite made of cellulose, hemicelluloses, lignin, etc. In addition, it can be extracted from other natural sources including bacteria, algae, and sea animals. Microcrystalline cellulose (MCC), nanocrystalline cellulose (NCC), and nanofibrillated cellulose (NFC) is an emerging renewable nanomaterial that has various applications, such as food, paper production, industrial and pharmaceutical biomaterials. The surface modification on NCC can improves its disperse ability in different solvents and its utilization in protein immobilization, tissue engineering, drug delivery, and inorganic reaction template. Therefore, based on recent studies, this review illustrated considerable progresses with addressing medicinal properties involving antimicrobial and biocompatibility of nanocellulose (NC) in the case of wound healing.
\end{abstract}

Keywords: nanocrystalline cellulose; nanofibrillated cellulose; microcrystalline cellulose; antimicrobial activities; wound healing

\section{Introduction}

The most abundant biopolymer in nature, which is biodegradable, biocompatible, as well as renewable, is cellulose (1). Cellulose with a formula of $\left(\mathrm{C}_{6} \mathrm{H}_{10} \mathrm{O}_{5}\right)_{n}$

* Corresponding author: Mehran Alavi, Department of Nanobiotechnology, Faculty of Science, Razi University, Kermanshah, Iran, e-mail:mehranbio83@gmail.com. is a carbohydrate linear polymer including repeated $\beta$-D-glucopyranose units by linkage of $\beta(1 \rightarrow 4)$ and with three hydroxyl groups per anhydroglucan unit providing high capacity of its surface modification (2). The molecular structure of this biopolymer is important as it gives the specific properties to cellulose, such as biodegradability, hydrophilicity, chirality, and high functionality $(3,4)$. Cellulose and its derivatives, as renewable biomaterial have been more studied, focusing on their chemical, biological, as well as mechanical properties $(5,6)$. More than 150 years, materials composed of cellulose and derived cellulose have been utilized in a wide variety of applications, such as food packaging, paper production, biomaterials, and pharmacy industry $(2,7)$.

Introducing of nanotechnology by famous physicist Richard Feynman in 1959 has had substantial impact on other sciences and technology directly and indirectly. In this way, nanomaterials at nano $\left(10^{-9} \mathrm{~m}\right)$ scale with unique properties such as large surface area to volume ratio have been applied in energy production, electronic, optic, catalyst, and medicine fields. Based on source of nanomaterials synthesis, there are organic, semi-organic, and synthetic nanomaterials. Moreover, nanomaterials can be in various forms such as fullerene, liposomes, dendrimer, carbon nanotube, graphene, and metal nanoparticles (MNPs) (8-12). Among these nanomaterials, NCC is a new class of nanomaterials which is obtained by acid hydrolysis, mechanical, oxidative and enzymatic treatments of cellulose fibers (13-16). NCCs compared to cellulose fibers, have more advantages, such as nanoscale dimension, high surface area, high specific strength and modulus, unique optical characteristics, etc. $(1,5,17)$. These prominent physicochemical properties and wide prospective of application have made significant interest from both scientific researches and industry applications $(18,19)$. In this way, usefulness of NCs applications as NFC, NCC, and also nanocomposites with other polymers was considered by food and drug association (FDA) and 
American forest and paper association (AF\&PA) (20). Optical and mechanical properties of $\mathrm{NC}$ are unique and therefore this polymer is efficient as a building block for a various cellulosic products through self-assembly or others ways (21). Biofuels production from cellulosic materials can reduce air pollutants by reduction of greenhouse gas emissions (22,23). It can be applied mechanical or chemical methods to prepare NCs based on the crystalline nature of cellulosic materials (24). For instance, ethanol biofuel is resulted from further hydrolysis of dissolved cellulose by fermentation or catalysis. Also, Zhu and coworkers investigated on production of NFC and cellulosic biofuel by enzymatic hydrolysis of wood fibers (25).

Although, cellulose polymer has not antimicrobial activities by itself, high biocompatibility, aspect ratio (length to width ratio), and functionality degree of this biopolymer are leaded to antimicrobial application of cellulose nanocomposites with various antimicrobial agents (26). In this way, using of MNPs such as silver, copper, zinc oxide, and titania can be useful. This type of NPs has efficient antimicrobial effects on bacteria (gram positive and gam negative), fungi, and viruses $(9,27,28)$. It is worth to noting that antimicrobial properties of the cellulose/MNPs nanocomposites in wound healing of severe burns and ulcers is important issue specifically in prevention of bacterial infections (29). Therefore, in the final section of this review, based on recent investigations, antimicrobial activities and wound healing of cellulose/MNPs with some of antimicrobial agents were presented.

\section{Nanocomposite nature of cellulose}

Nanocomposite of cellulose is defined as mixture of hemicellulose, cellulose, and lignin by having one or more dimensions in 1 to $100 \mathrm{~nm}$ (30). Integrating of these macromolecules for synthesis of larger structures is key manner for the plants survival and morphology. However, some living organisms such as sea squirts related to tunicate family, apply natural cellulosic nanostructures (20). In this case, self-assembly is a key principle of liquid crystals with establishing ability of cellulose development. Liquid crystals can be participated in the organization of another natural material such as cholesterol and biomedical diagnostics (31).

Porosity indications of the fibrillar nanostructures in natural cellulose such as hemp and cotton are one of the important aspects of these structures. In this way, pores sizes with 1 to $80 \mathrm{~nm}$ were determined for water swollen cellulosic fibers which prepared by sulfite pulping or kraft paper treatment (32). Firstly, bleaching and pulping increased the pores in cell walls of woodderived fibers, but eventually high levels of lignin removal can result in overall shrinking of the material, by a reduction in average pore size (33). Refining based on mechanical processes results in augmentation of the sizes of nanopores within cellulose fibers (34), whereas pressing and drying treatments lead to close some of the nanopores (35).

\section{Shapes and sizes of cellulosic structures}

In the case of cellulose, the word "fibril" is common word among investigators to explain long and very thin segments of cellulosic materials $(36,37)$. Also, the word nanofiber explains materials with very small cellulosic fibrous and functionality that differs from what has been in bulky cellulosic fibers (38). In the other words, nanofibers are commonly self-assemblies of discrete polymeric units which can have diameter of $\leq 100 \mathrm{~nm}$ and constitute a fiber/strand network with aspect ratio of $>1 \mathrm{~nm}$ (39).

As a structural material, cellulose is extremely strong, with Young's modulus of about $250 \mathrm{GPa}$ and a tensile strength of around $5200 \mathrm{kN}-\mathrm{m} / \mathrm{Kg}$, eighteen times more than titanium $(40,41)$. Naturally, most cellulose is existing in plant lignocelluloses biomass as biocomposite of cellulose, hemicelluloses, and lignin (1). In order to effectively liberate cellulose from lignocellulosic biomass of elementary fibrils and nano-fibrils, advanced separation techniques are required. Also, due to production of $\mathrm{NC}$ from plant biomass, there are several techniques. The main process is acid treatment (acid hydrolysis), which produce the stable colloid suspensions of NCC with negative charges (42). This process has a very low efficiency around $40 \%$ and depends on various factors, such as cellulose sources, type of acid that is used for hydrolysis, reaction time, and temperature (43).

The term "microcrystalline cellulose" (MCC) is used in the case of products that have been applied for many years for pharmaceutical materials. These products can be extracted via sulfuric treatment of bleached wood fibers such as kraft paper, and then washing and drying stages (44). In this case, it has been reported that application of the spray-drying process for production of MCC generally resulted in crystals agglomeration of cellulosic elements with range shape of "stubby" to "fibrillar and small size by excess of $1 \mu \mathrm{m}$ (45). 


\section{Chemical characteristics of cellulose}

Structure of cellulose is based on an $180^{\circ}$ turn-screw $\beta-1$, 4-glucopyranoside cellulose polymeric chain which rise to abundant crystalline domain formations that are considered allomorph (46). These structures have high strength more than a comparable structural of steel sample (Figure 1). Nanocrystals of these domains that are obtained by acid hydrolysis, result in intrinsic strength (47). These structures can provide reinforcement in a various composites; but, the major problem is weak interactions between polar (cellulose) and non-polar components in composites. Therefore, surface modification is highly required, which can generally be done to the cellulosic part followed by cross linking (48).

\section{Sources of NC structures}

\subsection{Herbal materials}

\subsubsection{Wood}

There are four major sources for obtaining of $\mathrm{NC}$ in nature (Figure 2). Due to its great frequency, wood can be used as precursor material for cellulose and NC extraction. Although, this process needs several stages for extraction and purification of cellulosic structures with size range within 1-100 nm (49). For instance, a method has been reported in which crushing of the water-soaked wood materials is followed by chemical treatment, mechanical refining, and homogenization in medium of liquid nitrogen temperature. Most researchers have applied slightly or almost completely purified concentration of cellulose such as MCC. In addition, other researchers have utilized bleached kraft pulp. Usually, in order to production of MCC and cellulosic nanofibers, sulfuric acid is used for hydrolyzing bleached kraft pulp. It was applied enzymatic fractionation of wood fibers for generation of nano-fibrillated cellulose and cellulose biofuel (50). NFCs with diameter size in the range 3.5-9.5 $\mathrm{nm}$ were extracted from fibers of Pinus radiata pulp by TEMPO-mediated oxidation method (51). In another approach, grinding at a high shear and pressure was applied to produce NFCs from softwood pulp fibers with porosity in the range of $29-99.7 \%(52)$.

\subsubsection{Byproduct materials of agriculture}

In a comparative approach, the degree of cellulose crystallinity is changed from one organism to another. For example, longer nanocrystals can be produced by algae and tunicates cellulose microfibrils, which have highly crystalline cellulose (53). Wheat stalks pulp, bamboo pulp, sugar beet pulp, potato tubers, hemp, banana, rutabaga, swede root, flax, and soybean stock as byproduct materials have been applied as source materials for production of nano-cellulosic structures (54-60). In this way, NC with density of $1.3 \pm 0.03 \mathrm{~g} / \mathrm{cm}^{3}, 42.3 \pm 1.87 \mathrm{MPa}$, and $69.8 \%$ was extracted from wheat straw pulp by $\mathrm{H}_{2} \mathrm{SO}_{4}$ hydrolysis (43\%) and ultra-sonication (30 $\mathrm{min}$ at $22 \mathrm{kGz}$ ) treatment (61). In addition, extracted bamboo nanofibrils by mechanical and $\mathrm{NaOH}$-antraquinone stages in $170^{\circ} \mathrm{C}$ temperature were incorporated in polyvinyl alcohol (PVA) modified commercial cassava starch (FMM) as filler for enhancement of resulted nanocomposite (62).

\subsection{Marine animal's NC}

Important advantages of animal source for production cellulosic nanomaterials are the relative purity and suitable potential to generate almost pure NCC and NFC materials (63). Moreover, the applications of tunicate (sea animal)-obtained whiskers have been analyzed in a different methods (64). In comparison study, it has been

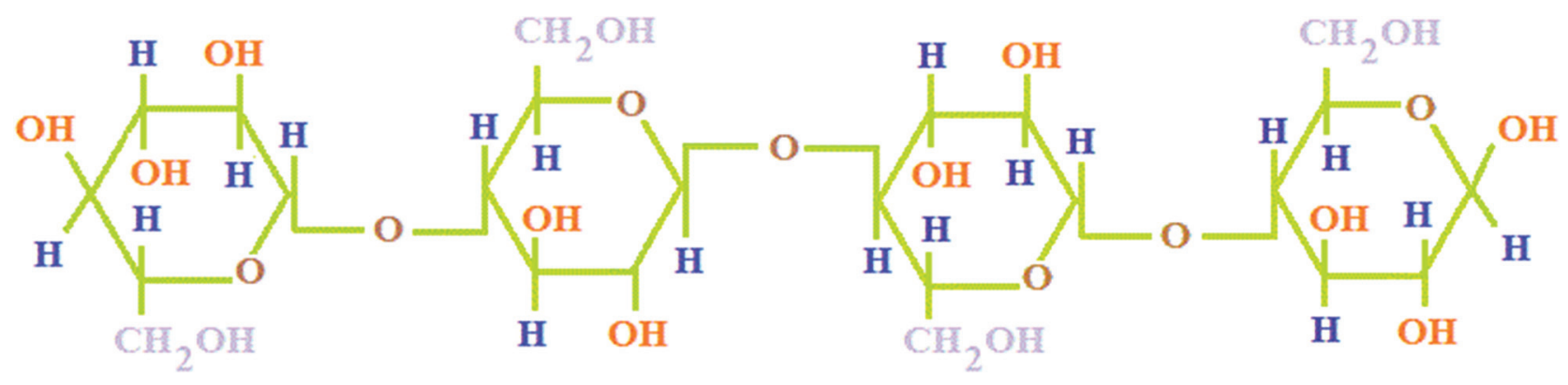

Figure 1: Structural formula of microcrystalline cellulose. 


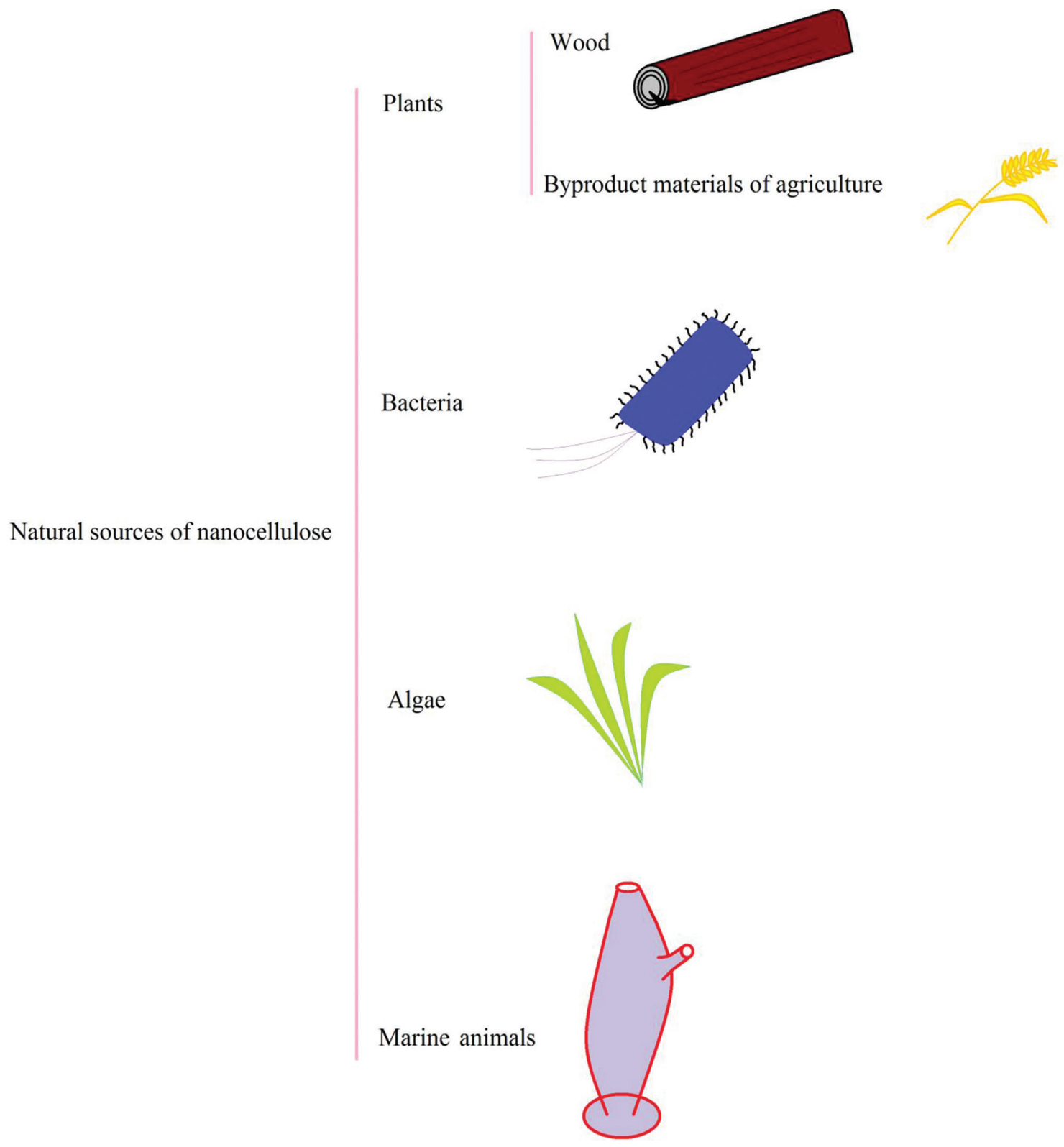

Figure 2: Natural sources for isolation of cellulose and NCs.

showed that NCC had higher quality with aspect ratio of $75 \pm 60$ than isolated NCC from plant (cotton pulp) and algae (seaweed) (65).

\subsection{Bacterial NC}

Studies on the synthesis, structure, and applications of cellulose have mainly carried out on plants, as they are the most producers of cellulose (66). Also, significant medicinal applications of cellulose structures have come from studies of bacteria (67). The bacterial-derived cellulose has several advantages such as high mechanical properties, light weight, non-toxicity, renewability, high chemical purity, and biodegradability (68). Based on a frequency of cheap carbon sources such as agro-industrial residues and wastewaters, production of bacterial cellulose (BC) represents a very interest source of cellulose nanofibers $(69,70)$.

Synthesis of BC is an extracellular primary metabolite by bacteria of the genera Gluconacetobacter, Agrobacterium, Acetobacter, Alcaligenes, Aerobacter, Enterobacter, Achromobacter, Pseudomonas, Rhizobium, and Salmonella (Table 1). Gram negative acetic acid bacteria Gluconacetobacter Xylinum belonging to the genus Gluconacetobacter is prominent cellulose producers (71). Aerobic bacteria synthesize cellulose only in the oxygenrich condition including on the surface of the fermentation vessel, the system becomes turbid and later a white 
Table 1: Various genera of bacteria with cellulose synthesis ability.

\begin{tabular}{llr}
\hline Genus & Species & References \\
\hline Gluconacetobacter & Gluconacetobacter Xylinum & $(74)$ \\
Agrobacterium & Agrobacterium tumefaciens & $(75)$ \\
Acetobacter & Acetobacter xylinum(Komagataeibacter & $(76)$ \\
& xylinus) & \\
& Acetobacter aceti & $(77)$ \\
Alcaligenes & Alcaligenes xylosoxydans & $(78)$ \\
Aerobacter & Aerobacter aerogenes & $(79)$ \\
Enterobacter & Enterobacter amnigenus & $(80)$ \\
& Enterobacter cloacae & $(81)$ \\
Cronobacter & Cronobacter sakazakii & $(82)$ \\
Achromobacter & Achromobacter sp. CX2 & $(83)$ \\
Pseudomonas & Pseudomonas putida & $(84)$ \\
& Pseudomonas fluorescens & $(85)$ \\
Rhizobium & Rhizobium endoglucanase & $(86)$ \\
& Rhizobium leguminosarum & $(87)$ \\
Salmonella & Salmonella enteritidis & $(88)$ \\
\hline
\end{tabular}

pellicle. Optimum temperature to cellulose synthesis is around $28-30^{\circ} \mathrm{C}(72)$. The interior of the bacterial cell wall is region of cellulose synthesis which it spinned out from protofibrils with approximately diameter by $2-4 \mathrm{~nm}$. Then, these structures are crystallized into microfibrils and bundles and later into ribbons. Microfibrils had a thickness of approximately 3-4 $\mathrm{nm}, 70-100 \mathrm{~nm}$ in width, and 1-9 $\mu \mathrm{m}$ in length (73). In this way, Acetobacter xylinum FF-88 strain was used to extract NFC with cellulose density in the range $5-1080 \mathrm{~kg} / \mathrm{m}^{3}$ and $28-99.7 \%$ porosity (52).

\subsection{Algal NC}

Algae have cellulose (cellulose I $\alpha$ type ) in cell wall as algic cellulose which is nearly similar to bacterial and plant cellulose and obtained after elimination of alginic acid (89). Various algae are characterized by having cellulose and NC. For example, Cladophora glomerata species was used as cellulose source for isolation of NFC through multi-stages process including treatment by distilled water washing, $1 \mathrm{wt} \% \mathrm{NaOH}$ solution preparation, $\mathrm{HCl}$ hydrolysis, and filtration at $80^{\circ} \mathrm{C}$. These nanomaterials had porosity range in $48-99.7 \%$ and NFC density with $5-780 \mathrm{~kg} / \mathrm{m}^{3}(52)$. In addition to green algae, NCC with $73 \%$ crystallinity was extracted from red algae such as Gelidium elegans in three stages including purification by $\mathrm{NaOH}$ sollution, bleaching with $\mathrm{H}_{2} \mathrm{O}_{2}$, and $\mathrm{H}_{2} \mathrm{SO}_{4}$ hydrolysis treatment (90). In similar study, it was utilized Gelidiella aceroso red algae species to prepare NCC by microwave pretreatment (360 $\mathrm{W}$ for $30 \mathrm{~min}$ ) in alkali condition. Extracted NCC had respectively average diameter and length of $23 \mathrm{~nm}$ and $408 \mathrm{~nm}$ (91).

\section{Modification of NC surface}

\subsection{Principles}

In composites synthesis, chemical compatibility between the filler material and continuous matrix is important. The surface of cellulosic elements tends to be incompatible with many of plastic materials that are most significant in the production of composites, e.g. styrene, polyethylene, etc. Also, high ability of cellulosic fibers for absorption of water can be influenced by using various composite forms.

Surface modifications of cellulosic materials can be resulted by variety of direct reactions involving the hydroxyl groups. In this case, there are two major approaches by hydroxyl substitution and polymer grafting for covalent surface modification of cellulose (Figure 3). Esterification and silanations are two common reactions for surface modification. In addition, bifunctional reagents, polymerization, surface activation, and organometallic chemistry can be used as alternative reactions. Most of these modifications improve dispersabiliy and compatibility in different solvents or matrices. There are potential applications for modified nano cellulosic materials in variety of industrial sectors, such as nanocomposites, biomaterials, personal care, etc. (46). In this way, in below section, some of significant modifications of cellulose surface with medicinal and antimicrobial applications are presented.

\subsection{Acetylation}

There are several methods for acetylation and esterification of cellulose and NCC. Acetylation of cellulose may be possible via homogenous and heterogeneous conditions, which determined by solubility degree of cellulose. In according to a non-swelling reaction, the reaction only is occurring on the cellulose chains located on NCC surface. By using a simple reaction such as Fischer esterification process in single step, NCC were synthesized and functionalized at hydroxyl groups (Figure 4) (92). Susceptibility and accessibility of hydrolyzed NCC on the surface are restrictive factors on the acetylation extent. In this way, acetic anhydride $\left(\left(\mathrm{CH}_{3} \mathrm{CO}\right)_{2} \mathrm{O}\right)$ and acetic acid $\left(\mathrm{CH}_{3} \mathrm{COOH}\right)$ are applied to modify the fibrous and homogenous cellulose. Both NFC and NCC were acetylated to improve physicochemical properties of NC. For example, in the case of NFC, dispersion, hydrophobicity, aspect ratio, transmittance, and thermal stability were increased for application in a flexible organic light-emitting device (FOLED) substrate (93). In this work, ratio of NFC to acetic 


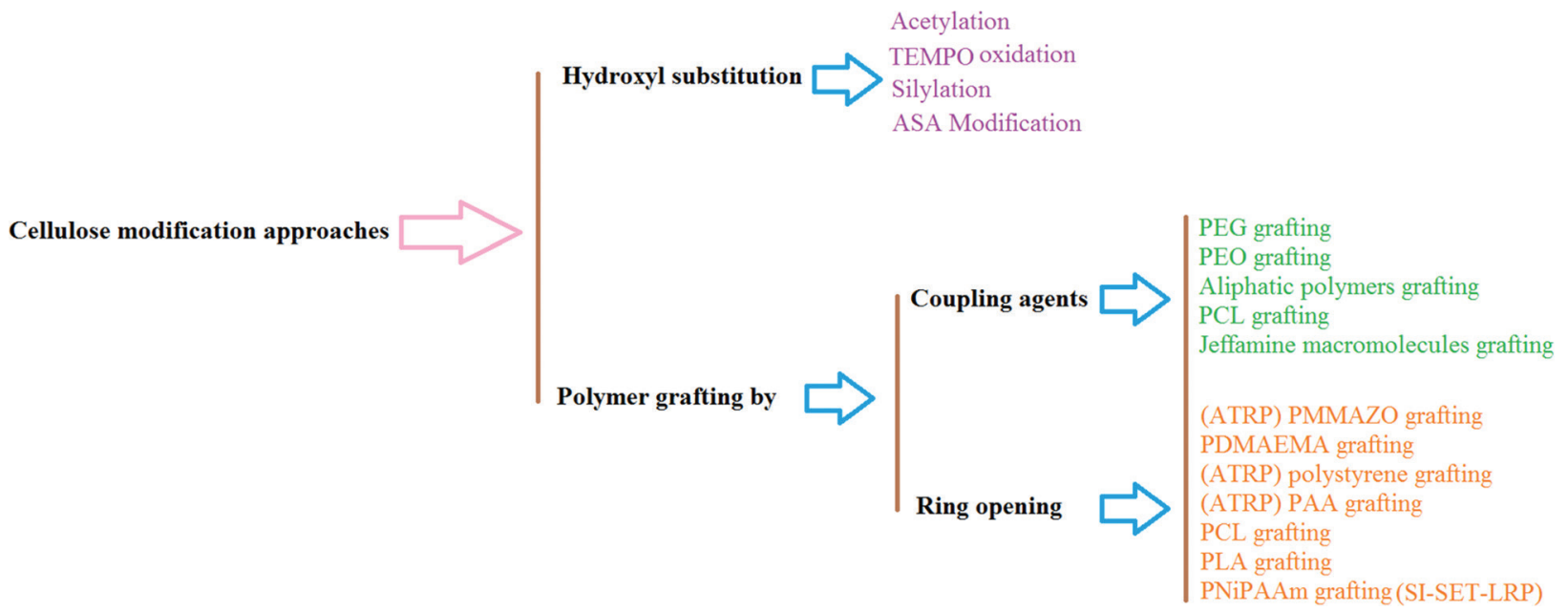

Figure 3: Modification of cellulose surface by two prominent ways. ATRP: atom transfer radical polymerization; PNiPAAm: poly(Nisopropylacrylamide); PDMAEMA: poly(N,N-dimethylaminoethyl methacrylate); SI-SET-LRP: surface-initiated single-electron transfer living radical polymerization; TEMPO: 2,2,6,6-tetramethylpiperidine-1-oxyl; PAA: poly(acrylic acid); PCL: poly(caprolactone); PEO: poly(ethylene oxide); PEG: poly(ethylene glycol); PLA: poly(lactic acid); ASA: (Alkenyl succinic anhydride).

\begin{tabular}{|llllllllllllllll}
$\mathrm{OH}$ & $\mathrm{OH}$ & $\mathrm{OH}$ & $\mathrm{OH}$ & $\mathrm{OH}$ & $\mathrm{OH}$ & $\mathrm{OH}$ & $\mathrm{OH}$ & $\mathrm{OH}$ & $\mathrm{OH}$ & $\mathrm{OH}$ & $\mathrm{OH}$ & $\mathrm{OH}$ & $\mathrm{OH}$ & $\mathrm{OH}$ \\
\hline $\mathrm{OH}$ & $\mathrm{OH}$ & $\mathrm{OH}$ & $\mathrm{OH}$ & $\mathrm{OH}$ & $\mathrm{OH}$ & $\mathrm{OH}$ & $\mathrm{OH}$ & $\mathrm{OH}$ & $\mathrm{OH}$ & $\mathrm{OH}$ & $\mathrm{OH}$ & $\mathrm{OH}$ & $\mathrm{OH}$ & $\mathrm{OH}$
\end{tabular}

Acid Dissociation and Cellulose Hydrolysis:

Fischer Esterification of Hydroxyls:

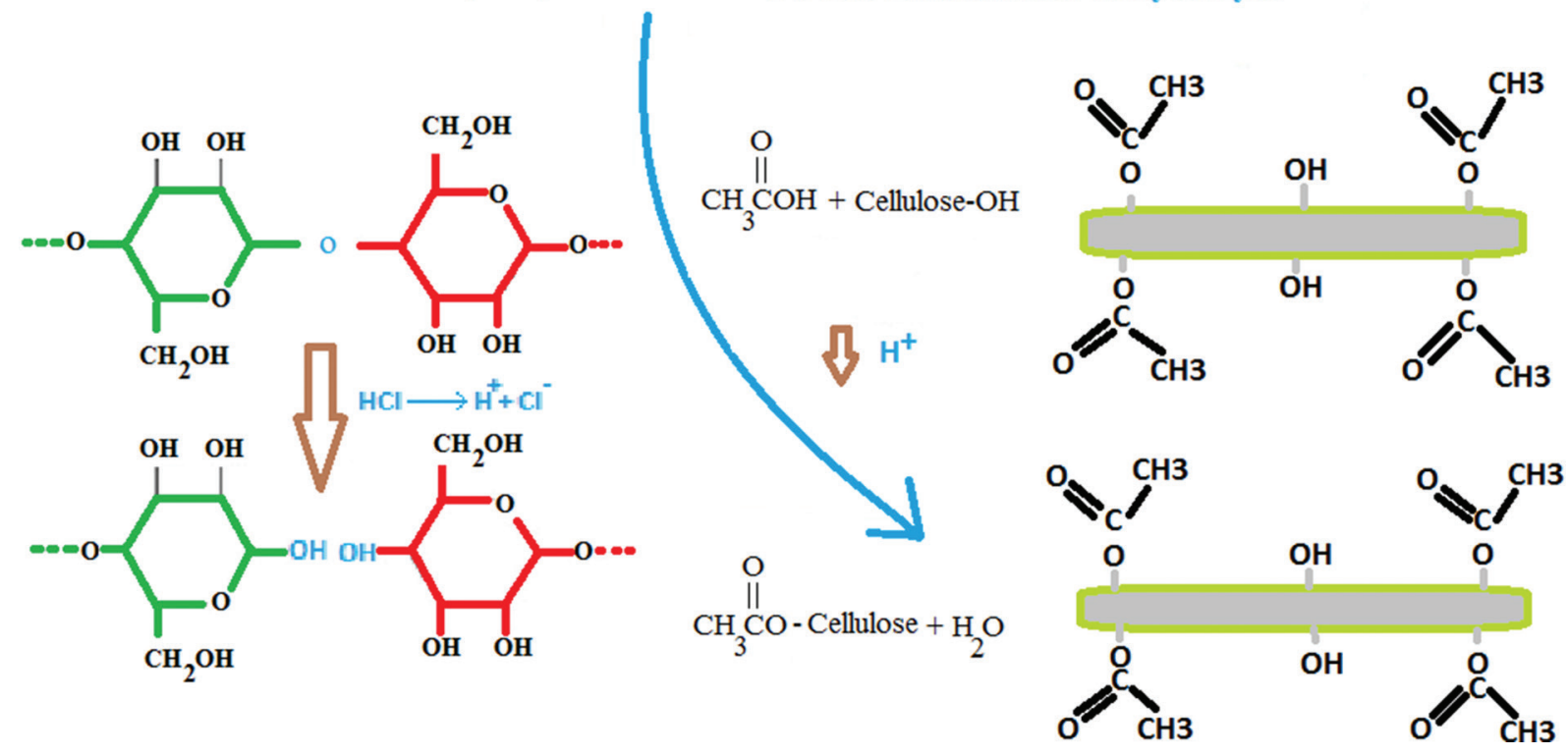

Figure 4: Scheme of cellulose hydrolysis and esterification of hydroxyl (OH-) groups via hydrochloric and acetic acids (reproduced from (92)).

anhydride was decisive factor. In another investigation, for obtaining of homogeneous acetyl CNC, acetic anhydride (AA) was added to anhydrous pyridine solution of CNC followed by heating at $80^{\circ} \mathrm{C}$. Different molar ratio of AA: hydroxyl groups showed various hydrophobicity degree and mechanical values (94).

\subsection{Cationization}

Cellulose having hydroxyl groups on the surface has negative charge intrinsically. Therefore, cationization can be possible by addition of materials as inducer positive chargesuchasstarch,2,3-epoxypropyltrimethylammonium 
chloride, and glycidyltrimethylammonium chloride. For example, cationization of eucalyptus pulps is carried out by glycidyltrimethylammonium chloride as efficient method to extract NFC. In this case, antibacterial activity of nanocomposites of cationic NFC with PVA was significant against Staphylococcus aureus and Salmonella enteric (95). In addition, hydroxyl groups of NFC were cationized via the trimethoxysilane group of (3 trimethoxysilylpropyl) phenanthridinium iodide with fluorescence properties and antibacterial effect on E. coli, S. aureus, B. subtilis, and $P$. aeruginosa by growth inhibition values of $17.5 \pm 0.7$, $15.5 \pm 0.7,12.5 \pm 0.7$, and $8.5 \pm 0.7 \mathrm{~mm}$ (96).

\subsection{NCC labeled by fluorescent}

Fluorescence techniques were extensively used to study the cellular uptake and biodistribution of nanoparticulate delivery systems, by tracking the localization of the fluorophores. Dong and Roman described a method to label NCC with fluorescein-5-isothiocyanate (FITC) for fluorescence bioassay and bioimaging applications (97). To covalently attach FITC moieties to the surface of NCC, they developed a simple method involving three steps of reaction pathway described by the reaction route shown in Figure 5. At first, the surface of NCC was decorated with epoxy functional groups via reaction with epichlorohydrin, and then the epoxy ring was opened with ammonium hydroxide to introduce primary amino groups. Finally, the primary amino group was reacted with isothiocyanate group of FITC to form a thiourea. They compared the UV/vis absorption spectrum of unlabelled and FITClabeled NCC in their suspensions, and found the absorption peaks of FITC in the wavelength range of $450-500 \mathrm{~nm}$ in the spectrum of the FITC-labeled NCC.

\section{Nanocomposites of cellulose with antimicrobial agents}

\subsection{Antimicrobial activities}

Herbal and bacterial derived NCs themselves have no antimicrobial activities. In this way, nanocomposite
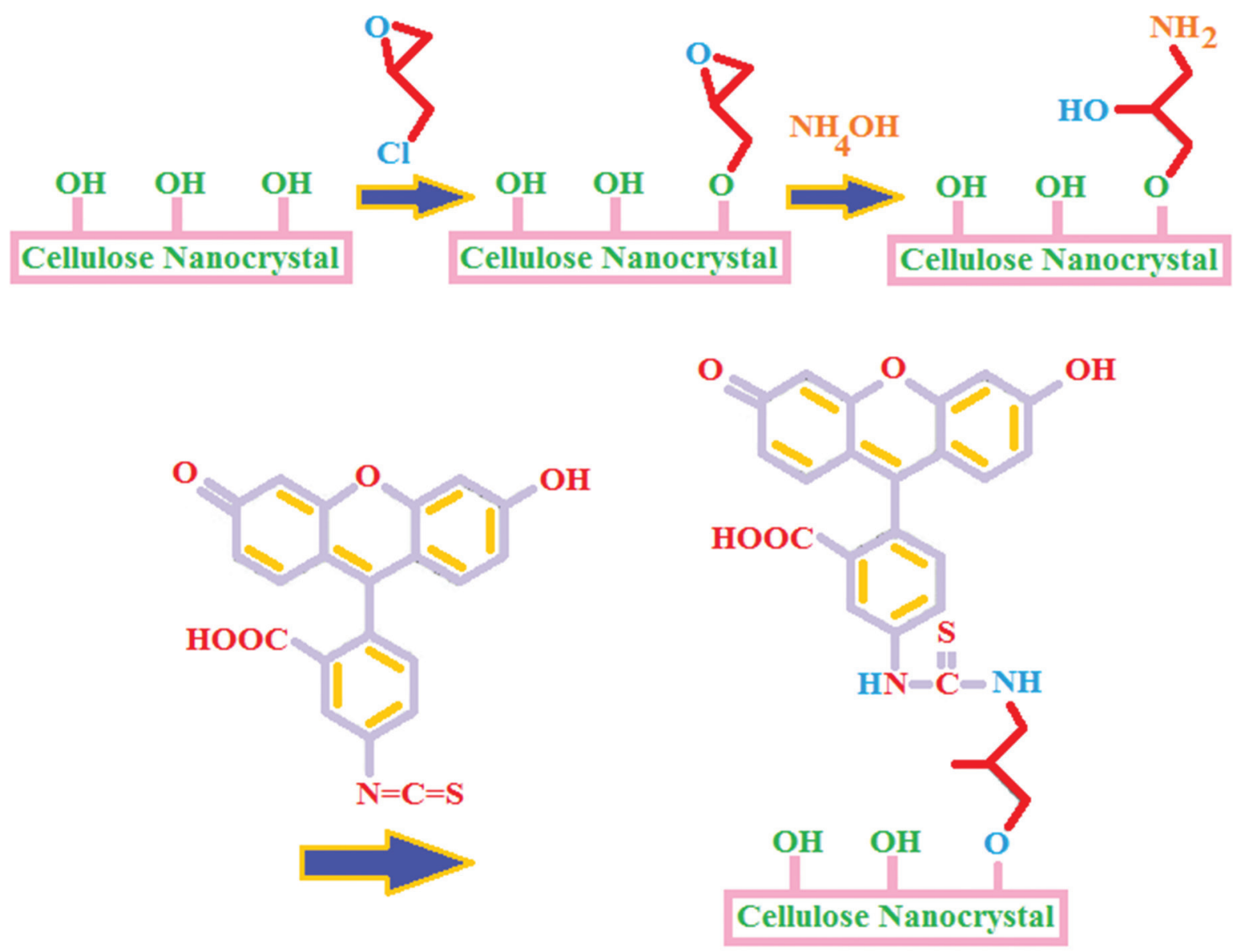

Figure 5: Reaction route for surface fluorescently labeled NCC with FITC (reproduced from (97)). 
structures of $\mathrm{NC}$ with antimicrobial agents were applied efficiently. Higher mechanical stability and biocompatibility are two important properties which made NCs as suitable carrier for antimicrobial agents as well as scaffold in wound dressing. Based on scaffold structure of NCs, entering of pathogens is more difficult. Also, align of nanofibers in NCs structure supplies moisture condition and pores for exchange of essential gases which lead to pain reduction and increasing of wound healing (98). In the below sections, nonocomposites of NCs with antimicrobial agents were described.

\subsection{Silver NPs}

Biological and biomedicinal aspects of physicochemical and biogenic synthesized sliver NPs specifically their antimicrobial activities were approved by many investigations (99-103). In recent years, emerging of multi drug resistant (MDR) microorganisms with high frequency leads to offering new antimicrobial agents such as silver nanoparticles in microbial infections therapy (104). Abilities of silver NPs as antibacterial, antifungal, and antiviral are dependent on different properties of these NPs involving large surface area to volume ratio $(\mathrm{SA}: \mathrm{V})$ than their bulk material. Antimicrobial activities of silver NPs are resulted specifically from release of high reactive ions of silver $\left(\mathrm{Ag}^{+}\right)$from NP surface which receive one electron from neighbor molecules to create reduced element of silver $(\mathrm{Ag})$ and production of oxidized molecules or radical species in environment. As illustrated in Figure 6, this reaction in bacterial environment can influence on cell wall, cell membrane, enzymes, and genetic functions of microbes. Two factors of size and shapes of NPs are important in antimicrobial activity. As, Smaller size than larger one has higher reactivity. In addition, it was indicated that various shapes of Ag NPs involving hexagonal, spherical, and triangular showed different effects on bacterial viability (105).

Treatment of fungal infections specifically in immunocompromised patients is a heavy work because of low efficiency of antifungal drugs. In this way, presentation of novel antifungal agents by having biocompatibility and ecofriendly properties is vital. Silver NPs had antifungal activities on Candida spp. without cytotoxicity at $30 \mathrm{mg} / \mathrm{L}$ concentration (106). Candida albicans and Aspergillus niger demonstrated sensitivity at $25 \mu \mathrm{g} / \mathrm{mL}$ of minimum inhibition concentration (MIC) (107). Antiviral performance against HIV viruses at early stages of replication with functions of prevention of CD4-dependent virion binding, fusion, and infectivity was surveyed in the case of silver NPs (108).

The antibacterial activities of the Ag NPs-cellulose fibers with $0.005 \%$ to $3 \% \mathrm{w} / \mathrm{w}$ of silver element were significant against E. coli and S. aureus bacteria (109). Hybrid gel-membrane of bacterial CNF/silver NPs was utilized as a wound dressing nanomaterial with antibacterial effect on Pseudomonas aeruginosa, E. coli, and $S$. aureus bacteria. Antibacterial results of this study showed 1.04-2.35 mm range of inhibition zone diameters and $98.8-100 \%$ reduction in all three bacterial species (110). In another study, silver NPs are bounded on bacterial NC (BNC) synthesized from Gluconacetobacter xylinus strain DSM 14666. Results of this study illustrated 99\% reduction in population of $E$. coli than to pure BNC (111). Antibacterial activities of the composites of silver NPs

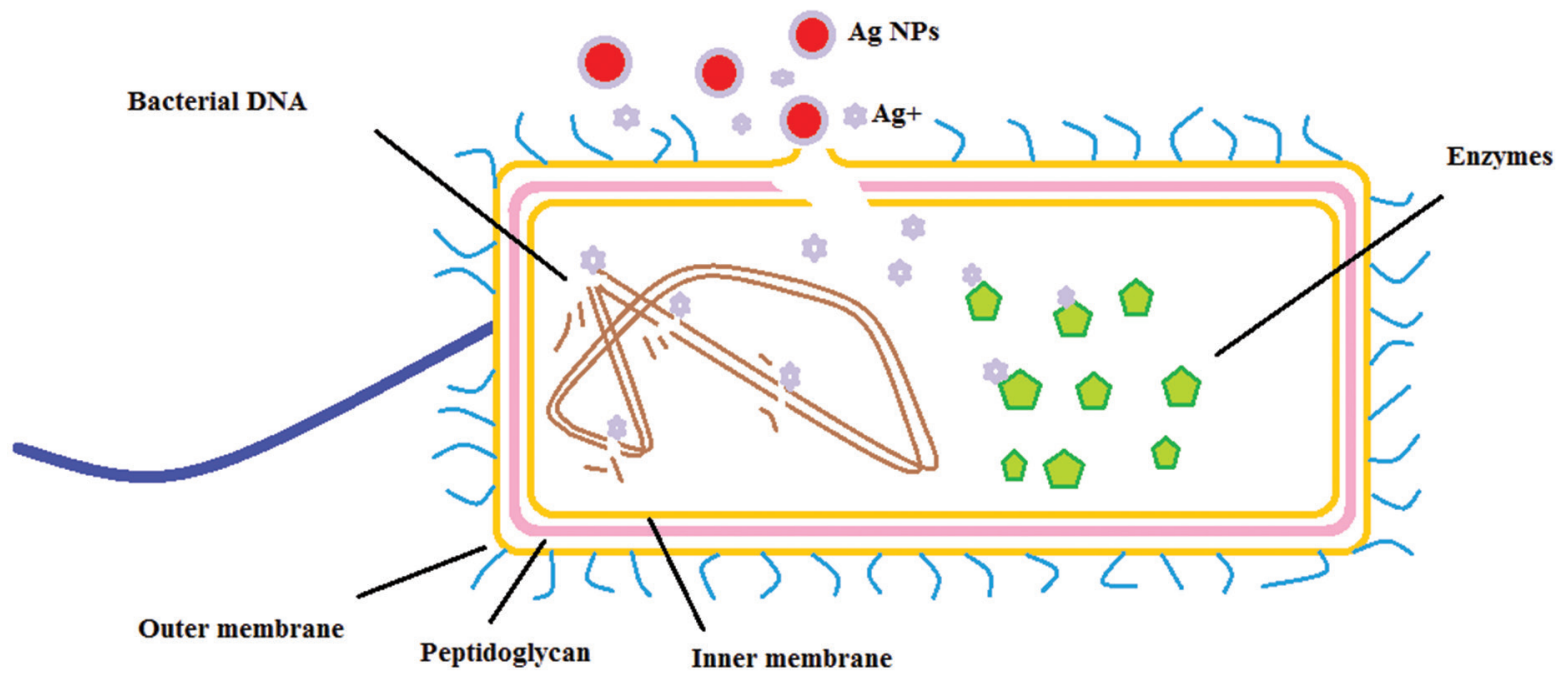

Figure 6: Basic antibacterial mechanisms of silver NPs. 
and dopamine-conjugated with carboxylated cellulose nanofibers (CCNF) against gram negative (E. coli) and gram positive (S. aureus) bacterial species illustrated meaningful diameter of inhibition zones by $718.45 \pm 87.17 \mathrm{~mm}^{2}$ and $1056.57 \pm 140.18 \mathrm{~mm}^{2}$ respectively (Figure 7) (112).

\subsection{Copper NPs}

Antimicrobial properties of copper NPs as forms of $\mathrm{Cu}$, $\mathrm{CuO}, \mathrm{Cu}_{2} \mathrm{O}$, and $\mathrm{CuS}$ were surveyed by several investigators in vitro and in vivo $(10,27,113,114)$. Cost effective of $\mathrm{Cu}$ NPs is one of their major advantages compared to Ag NPs. Lower cytotoxicity of copper than silver as an another advantage is resulted from specific function of protective mechanisms, against copper in human body (115). Copper NPs coated cellulose film showed 3-log and 4-log reduction in E. coli and $S$. aureus pathogens after $30 \mathrm{~min}$ incubation (116). Nanocomposites of $\mathrm{Cu}$ NPs-loaded chitosanattached cellulose compared to cotton cellulose fibers and chitosan-attached cellulose had higher antibacterial effect on E. coli (117). Eight-log population reduction of Acinetobacter baumannii as a multidrug resistant wound pathogen was observed for $\mathrm{Cu}$ NPs coated cotton cellulose at concentration of $30 \mu \mathrm{g} / \mathrm{mL}$ with low cytotoxicity (118). Antibacterial activity of vegetable cellulose/Cu NPs and bacterial cellulose/Cu NPs composites against $S$. aureus and Klebsiella pneumoniae in different concentrations of $\mathrm{Cu}(\% \mathrm{w} / \mathrm{w})$ demonstrated shape, Cu content, and bacterial type dependent pattern (119). In addition, S. aureus ATCC 6538 showed $90 \%$ reduction of bacterial viability after $3 \mathrm{~h}$ incubation under treatment of $\mathrm{Cu}_{2} \mathrm{O}$ surface modified cellulose fibers with value of $2.6 \mathrm{mmol} \mathrm{Cu} / \mathrm{kg}$ cellulose fiber (120).

\subsection{Zinc oxide NPs}

Other metal NP with antimicrobial ability which was used as nanocomposites with cellulose and $\mathrm{NC}$ is zinc oxide NPs. As illustrated in Figure 8, preparation of ZnO NPs coated cellulose via dispersion of $\mathrm{ZnO}$ NPs in aqueous $\mathrm{NH}_{4} \mathrm{OH}$ $(\mathrm{pH}=8)$ and remove of $\mathrm{NH}_{4}^{+}$in next step was carried out with having antibacterial activity against $E$. coli 11634 (121). Photoactivity and oxidizing antibacterial mechanisms of $\mathrm{ZnO}$ NPs were reported by several studies $(9,122,123)$.
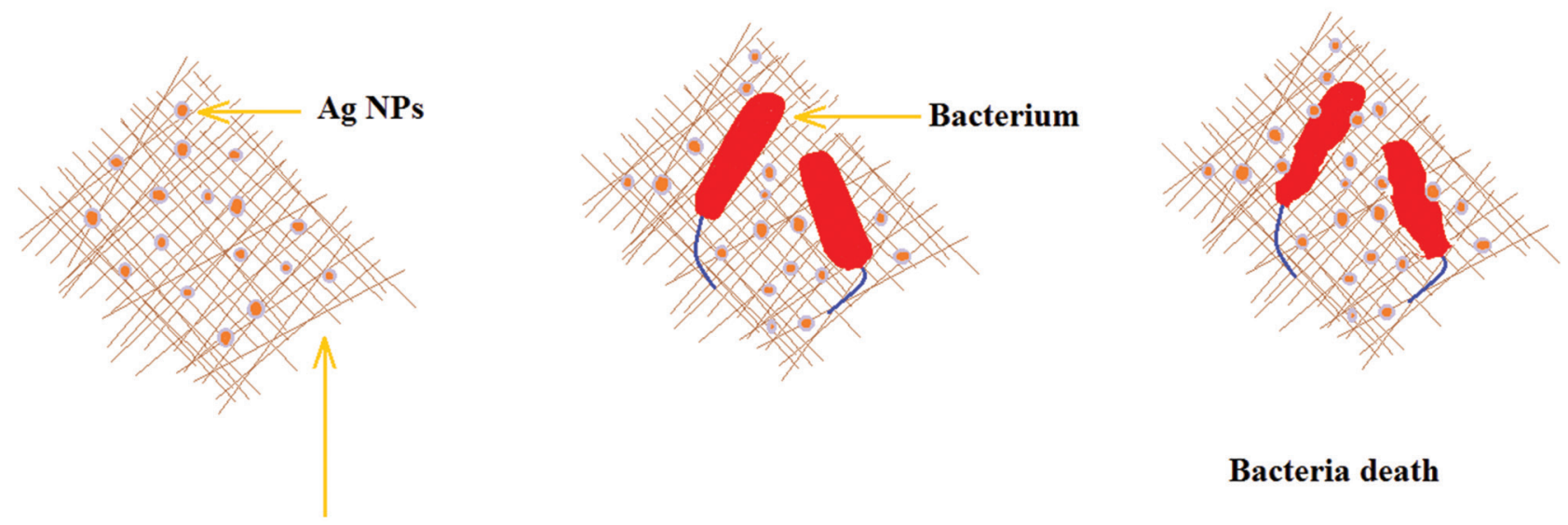

\section{CCNF}

\section{Bacteria death}

Figure 7: Antibacterial activity of the anisotropic carboxylated cellulose nanofibers (CCNF)-dopamine/Ag NPs nanocomposite (reproduced from (112)).

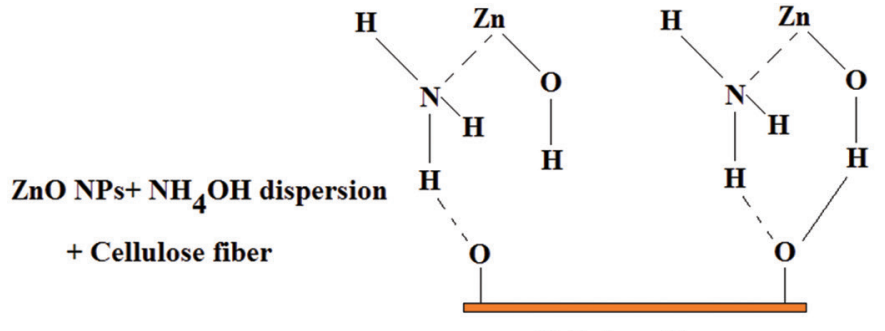

Cellulose fiber
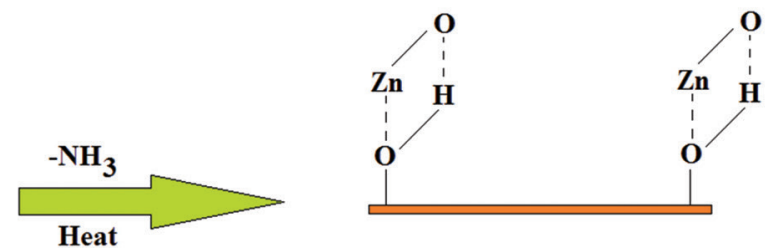

Figure 8: Schematic diagram for coating steps of $\mathrm{ZnO}$ nanoparticles on cellulose fibers (reproduced from (121)). 

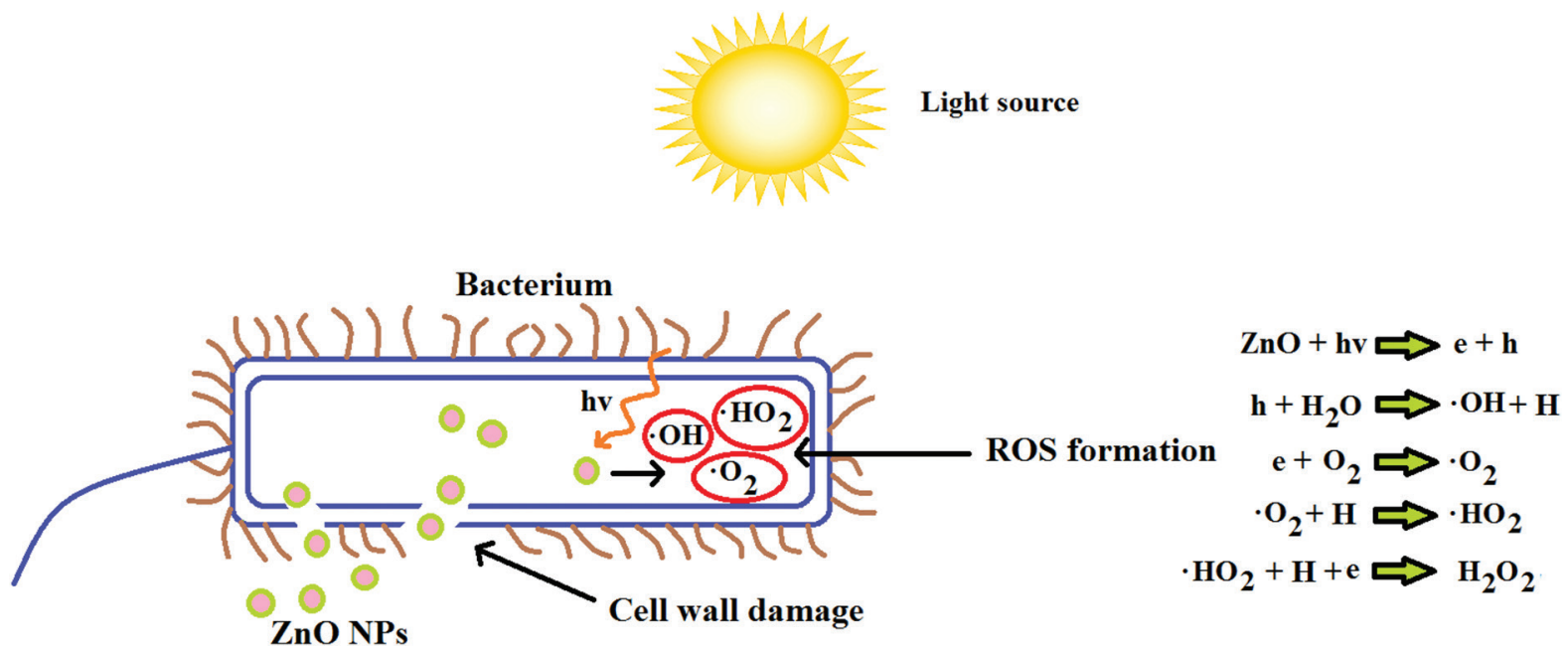

Figure 9: Antibacterial mechanisms of ZnO NPs by production of ROS (9).

Toxicity mechanisms of $\mathrm{ZnO}$ NPs via production of reactive oxygen species (ROS) involving hydrogen peroxide $\left(\mathrm{H}_{2} \mathrm{O}_{2}\right)$, superoxide $\left(\mathrm{O}_{2}^{\bullet}\right)$, and hydroxide $(\mathrm{HO} \bullet)$ anions are shown in Figure 9. Moreover, these mechanisms were illustrated by using electrostatic synthesized $\mathrm{NFC} / \mathrm{ZnO} \mathrm{NPs} / \mathrm{starch}$ nanocomposites against $S$. aureus, Bacillus cereus, and Klebsiella pneumoniae pathogens (124).

In another study, NCCs were applied as a stabilizer part in nanocomposites of $\mathrm{Zn}-\mathrm{Ag}$ NPs with various amounts of $\mathrm{AgNO} 3$ than $\mathrm{Zn}(\mathrm{AcO}) 2.2 \mathrm{H} 2 \mathrm{O}$ as reducers. Comparatively antibacterial survey of this nanocomposite with $\mathrm{ZnO}-\mathrm{Ag}$ free-cellulose showed higher inhibition zone diameter for $\mathrm{ZnO}-\mathrm{Ag} / \mathrm{CNCs}$ by higher concentration of $\mathrm{AgNO}_{3}(10.0 \mathrm{wt} \%$, relative to $\mathrm{Zn}(\mathrm{AcO}) 2 \cdot 2 \mathrm{H} 2 \mathrm{O})$ as values of 13.6 and $12.7 \mathrm{~mm}$ for respectively $\mathrm{S}$. aureus and Salmonella choleraesuis bacteria (125). One-step coagulation synthesis of cellulose/ZnO NPs composites had 2-3 log, 5-7 log and complete reducing effects on E. coli after 1, 3, and $6 \mathrm{~h}$ incubation time (126). Ultrasound assembled $\mathrm{ZnO} \mathrm{NPs} /$ bacterial cellulose films demonstrated higher antibacterial effect on E. coli and S. aureus with respectively $20.4 \pm 0.00$ and $7.6 \pm 0.05 \mathrm{~mm}$ than $\mathrm{ZnO} \mathrm{NPs} /$ bacterial cellulose films by $11.8 \pm 0.04$ and $5.6 \pm 0.01 \mathrm{~mm}$ of inhibition zone diameter (127). Moreover, antibacterial activities of nanocomposites of $\mathrm{ZnO}$ NPs/bacterial cellulose against Citrobacter freundii, E. coli, S. aureus, and P. aeruginosa showed respectively $90.9 \%, 90 \%, 94.3 \%$, and $87.4 \%$ inhibition (128).

\subsection{Titanium dioxide NPs}

Titanium dioxide $\left(\mathrm{TiO}_{2}\right)$ or titania is common oxide of $\mathrm{Ti}$ in nature with three crystal forms including rutile, anatase, and brookite (129). There are several reports related to antimicrobial abilities of $\mathrm{TiO}_{2}$ NPs $(130,131)$. It was illustrated cellulose/titania/chitosan/Ag NPs has higher antibacterial activities in the case of $E$. coli and $S$. aureus strains than cellulose/titania/chitosan. Antibacterial properties of titania part in these nanocomposites were resulted from bacteria adsorption onto the $\mathrm{TiO}_{2}$ surface (132). Bacteriostatic and bactericidal effects of regenerated bacterial cellulose/ $\mathrm{TiO}_{2} \mathrm{NPs}$ on $E$. coli pathogen are caused by oxidative stress mechanism. In addition, this nanocomposite had low cytotoxicity on fibroblast cells (133). Stabilizing of $\mathrm{TiO}_{2} \mathrm{NPs}$ by 0.005 and $0.002 \mathrm{M}$ concentration on carboxymethyl cellulose/PVA by gamma radiation illustrated respectively inhibition zone diameters as 12 and $10 \mathrm{~mm}$ (134).

\subsection{Other antimicrobial agents}

Lysozyme and allicin antimicrobial agents were conjugated with NC via cross-linker of a carbodiimide as lysozymeconjugated NC (LCNC) and allicin-conjugated NC (ACNC). Microdilution methods of $\mathrm{MIC}_{50}$ and $\mathrm{MIC}_{90}$ illustrated LCNC and ACNC had higher antimicrobial activities than NC and lower than lysozyme and allicin antibiotics against E. coli ATCC 25922, S. aureus ATCC 25923, Candida albican ATCC10231, and Aspergillus niger ATCC 16888 strains (135). In similar study, slower release rate, antibacterial properties against $S$. aureus, and significant biocompatibility ability on human keratinocytes were observed in the case of nococomposites of octenidine-BNC (136). Food packaging with efficient antimicrobial capacity is major issue in food industry. In this way, chitosan-NC was used to package the ground meat with meaningful antibacterial effects on 
E. coli, S. enteritidis, and S. aureus pathogens after 6 days of storage in $25^{\circ} \mathrm{C}$ temperature (137). In comparative study, loading of polihexanide and povidone-iodine antiseptic agents on bacterial NC demonstrated higher antibacterial effects of polihexanide-loaded BNC but lower biocompatibility than povidone-iodine-loaded BNC on S. aureus (138). Similarly, loading of laccase on BNC as nanocompsites for wound dressing application showed $92 \%$ and $26 \%$ reduction in bacterial population of $S$. aureus and E. coli respectively with low cytotoxicity (139).

\section{Wound healing by cellulose nanocomposites}

Skin organ is composed from three tissue layers of epidermis, dermis, and hypodermis (Figure 10). There are two types of wound involving chronic and acute wounds which formed resulted from thermal, physical, and chemical hurts. Wound healing or "cascade of healing" can be performed via five stages of haemostasis, inflammation, migration, proliferation, and remodeling or maturation. Healing periods for acute and chronic wounds are respectively 8-12, and more than 12 weeks $(140,141)$. Wound healing of burns, injuries, and chronic ulcers such as diabetic ulcers is complicated issue when microbial infections are involved. Traditional, biological, and artificial dressings can be sued for wound healing. Among artificial dressing, using of natural polymers such as cellulose has major advantages of biocompatibility, biodegradability, suitable mechanical properties, and inherent permeability to water. Removal of wound dressings after healing is a hindrance in application of not degradable polymers. Biodegradability of cellulose polymer is related to function of cellulase enzyme of bacteria in nature. However, human body has not this

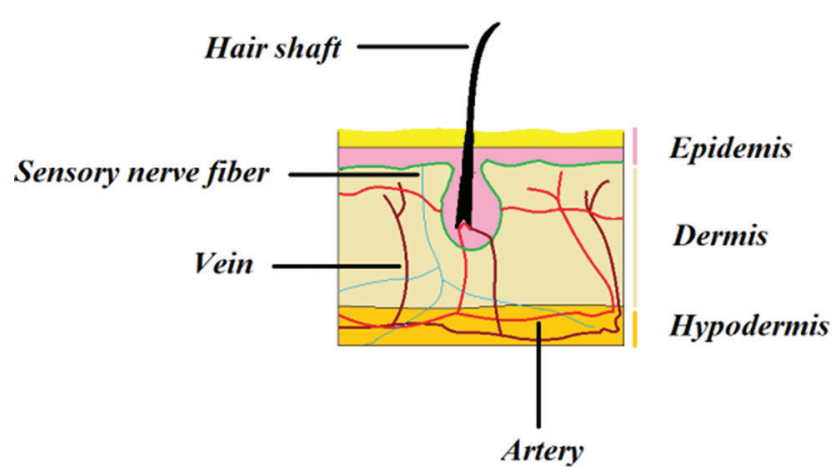

Figure 10: Schematic showing three layers with their important components of skin tissue. enzyme and therefore, modified or derivatives forms of this polymer are frequently used for wound dressing. In this regard, glucose polymer of dextran was used to improve biodegradability of $\mathrm{BC}$ and cell proliferation in wound site (142). In another study, loading of chloramphenicol in 2,3-dialdehyde cellulose hydrogel showed higher biodegradability and drug release. Results of disc diffusion test for this study were 9,11 , and $13 \mathrm{~mm}$ against E. coli, S. aureus, and Streptococcus pneumoniae respectively (143). Bacterial infections caused by gram positive (S. aureus and Enterococcus faecalis) and gram negative bacteria ( $P$. aeruginosa) are significant in single or multi-bacterial wound infections (144). In addition, sufficient moist, oxygen, temperature, growth factors, and bioactive materials are essential in fast healing of wound (145). Burn wound healing ability of bacterial cellulose/ZnO nanocomposites compared to silver sulfadiazine illustrated significant reduction in wound area as values of $66 \%$ than $77 \%$ respectively after fifteen days of treatment (128). Cellulose polymer specifically NCC and NFC with having high degree of functionality and biocompatibility are a suitable alternative for wound healing. $\mathrm{Lu}$ and his coworkers used sodium periodate to oxidize hudroxyl group on NFC for integration of collagen polymer. This nocomposite were prepared by cross link between amino groups of collagen with the aldehyde groups of functionalized NFC. Water absorption, porosity, and density of collagen/NFC were respectively $4000 \%, 95 \%$, and $0.03 \mathrm{~g} / \mathrm{cm}^{3}$ (146). In another study, NC was oxidized and carboxymethylated by respectively periodate and TEMPO for using as a bioink material with growth inhibition ability in the case of $P$. aeruginosa PAO1 (147). Comparative study about mechanical and cytotoxicity of nanocomposites prepared by NCCs and chitosan polymer showed significant water absorbance with biocombatibility effect on adipose derive stem cells (ASCs) and L929 cell line after period of 7 days (148). In a different study, using hemicellulose of xyloglucan into hydrogel scaffolds of NFC resulted in meaningful reinforcement and cell growth and proliferation in 3-D matrix structure (149).

\section{Conclusions}

In this review, natural sources and modification approaches of cellulose and NCs having antimicrobial and wound healing abilities were presented. It is worth noting that NCCs and NFCs are eco-friendly materials, which could serve as valuable reusable resources for revival forest industry specifically. New and emerging 
industrial extraction processes needed to be optimized to achieve more efficient operations through active research participations from the academic and industrial sectors. The application of nanotechnology in developing NCs from the forest industry to more valuable products is required, because the availability of materials based on NCs is still limited. Increasing attention is devoted to produce NCs in larger quantities, and to explore various modification processes that enhance the properties of NCC, making it attractive for use in a wide range of nanomedicine and industrial technology fields.

Base on some of the studies which were mentioned, it is reasonable to anticipate that most successful applications of NCs, as composite form, should be formulated from water miscible matrix materials, such as PVA, latex, starch products, etc. Utilizing of cellulosic nanoelements in such applications is similar to using hydrophilic cellulose fibers for the manufacture of paper, a product that is formed in the presence of water, but which is generally in dry condition. In the case of medicinal aspects, modifications of cellulose and NCs by antimicrobial agents such as MNPs and other antibiotic substances are important processes due to improvement of wound healing property of this polymer. Although, there are many investigations in this filed, but production of defect-free materials with efficient antimicrobial, porosity, moisture absorbency in wound region is required.

\section{References}

1. Brinchi L., Cotana F., Fortunati E., Kenny J.M., Production of nanocrystalline cellulose from lignocellulosic biomass: technology and applications. Carbohydrate Polymers, 2013, 94(1), 154-69.

2. Salam A., Lucia L.A., Jameel H., A novel cellulose nanocrystalsbased approach to improve the mechanical properties of recycled paper. ACS Sustainable Chemistry \& Engineering, 2013, 1(12), 1584-92.

3. Lee K.-Y., Tammelin T., Schulfter K., Kiiskinen H., Samela J., Bismarck A., High performance cellulose nanocomposites: comparing the reinforcing ability of bacterial cellulose and nanofibrillated cellulose. ACS Applied Materials \& Interfaces, 2012, 4(8), 4078-86.

4. George J., Sabapathi S.N., Cellulose nanocrystals: synthesis, functional properties, and applications. Nanotechnology, Science and Applications, 2015, 8, 45.

5. Peng B.L., Dhar N., Liu H.L., Tam K.C., Chemistry and applications of nanocrystalline cellulose and its derivatives: a nanotechnology perspective. The Canadian Journal of Chemical Engineering, 2011, 89(5), 1191-206.

6. Lavoine N., Desloges I., Dufresne A., Bras J., Microfibrillated cellulose-Its barrier properties and applications in cellulosic materials: A review. Carbohydrate Polymers, 2012, 90(2), 735-64.
7. Klemm D., Kramer F., Moritz S., Lindström T., Ankerfors M., Gray D., et al., Nanocelluloses: A new family of nature-based materials. Angewandte Chemie International Edition, 2011, 50(24), 5438-66.

8. Alavi M., Hamidi M., Passive and active targeting in cancer therapy by liposomes and lipid nanoparticles. Drug Metabolism and Personalized Therapy, 2019, 34(1), 1-8.

9. Taran M., Rad M., Alavi M., Biosynthesis of $\mathrm{TiO}_{2}$ and $\mathrm{ZnO}$ nanoparticles by Halomonas elongata IBRC-M 10214 in different conditions of medium. Biolmpacts, 2017, 8(2), 65-74.

10. Rad M., Taran M., Alavi M., Effect of Incubation Time, $\mathrm{CuSO}_{4}$ and Glucose Concentrations on Biosynthesis of Copper Oxide (CuO) Nanoparticles with Rectangular Shape and Antibacterial Activity: Taguchi Method Approach. Nano Biomed Eng, 2018, 10(1), 25-33.

11. Abraham J., Vasu K.S., Williams C.D., Gopinadhan K., Su Y., Cherian C.T., et al., Tunable sieving of ions using graphene oxide membranes. Nature Nanotechnology, 2017, 12(6), 546-50.

12. Kraemer Â.B., Parfitt G.M., da Silva Acosta D., Bruch G.E., Cordeiro M.F., Marins L.F., et al., Fullerene (c60) particle size implications in neurotoxicity following infusion into the hippocampi of Wistar rats. Toxicology and Applied Pharmacology, 2018, 338, 197-203.

13. Sacui I.A., Nieuwendaal R.C., Burnett D.J., Stranick S.J., Jorfi M., Weder C., et al., Comparison of the properties of cellulose nanocrystals and cellulose nanofibrils isolated from bacteria, tunicate, and wood processed using acid, enzymatic, mechanical, and oxidative methods. ACS Applied Materials \& Interfaces, 2014, 6(9), 6127-38.

14. Liu D.Y., Sui G.X., Bhattacharyya D., Synthesis and characterisation of nanocellulose-based polyaniline conducting films. Composites Science and Technology. 2014, 99, 31-6.

15. Salas C., Nypelö T., Rodriguez-Abreu C., Carrillo C., Rojas O.J., Nanocellulose properties and applications in colloids and interfaces. Current Opinion in Colloid \& Interface Science, 2014, 19(5), 383-96.

16. Anirudhan T.S., Deepa J.R., Synthesis and characterization of multi-carboxyl-functionalized nanocellulose/nanobentonite composite for the adsorption of uranium (VI) from aqueous solutions: Kinetic and equilibrium profiles. Chemical Engineering Journal, 2015, 273, 390-400.

17. Kaushik M., Basu K., Benoit C., Cirtiu C.M., Vali H., Moores A., Cellulose nanocrystals as chiral inducers: enantioselective catalysis and transmission electron microscopy 3D characterization. Journal of the American Chemical Society, 2015, 137(19), 6124-7.

18. Mihranyan A., Cellulose from cladophorales green algae: From environmental problem to high-tech composite materials. Journal of Applied Polymer Science, 2011, 119(4), 2449-60.

19. Yahya M., Lee H.V., Zain S.K., Hamid S.B.A., Chemical Conversion of Palm-based Lignocellulosic Biomass to Nano-Cellulose. Polymers Research Journal, 2015, 9(4), 385.

20. Hubbe M.A., Rojas O.J., Lucia L.A., Sain M., Cellulosic nanocomposites: a review. BioResources, 2008, 3(3), 929-80.

21. Lagerwall J.P.F., Schütz C., Salajkova M., Noh J., Park J.H., Scalia G., et al., Cellulose nanocrystal-based materials: from liquid crystal self-assembly and glass formation to multifunctional thin films. NPG Asia Materials, 2014, 6(1), e80.

22. Rubin E.M., Genomics of cellulosic biofuels. Nature, 2008, 454(7206), 841-5.

23. Langan P., Gnanakaran S., Rector K.D., Pawley N., Fox D.T., Cho D.W., et al., Exploring new strategies for cellulosic biofuels 
production. Energy \& Environmental Science, 2011, 4(10), 3820-33.

24. Wang Q., Zhu J.Y., Considine J.M., Strong and optically transparent films prepared using cellulosic solid residue recovered from cellulose nanocrystals production waste stream. ACS Applied Materials \& Interfaces, 2013, 5(7), 2527-34.

25. Tang X., Zuo M., Li Z., Liu H., Xiong C., Zeng X., et al., Green processing of lignocellulosic biomass and its derivatives in deep eutectic solvents. ChemSusChem, 2017.

26. Tang J., Sisler J., Grishkewich N., Tam K.C., Functionalization of cellulose nanocrystals for advanced applications. Journal of Colloid and Interface Science, 2017, 494, 397-409.

27. Alavi M., Karimi N., Characterization, antibacterial, total antioxidant, scavenging, reducing power and ion chelating activities of green synthesized silver, copper and titanium dioxide nanoparticles using Artemisia haussknechtii leaf extract. Artificial Cells, Nanomedicine, and Biotechnology, 2017, 1-16.

28. Sujitha V., Murugan K., Paulpandi M., Panneerselvam C., Suresh U., Roni M., et al., Green-synthesized silver nanoparticles as a novel control tool against dengue virus (DEN-2) and its primary vector Aedes aegypti. Parasitology Research, 2015, 114(9), 3315-25.

29. Singla R., Soni S., Kulurkar P.M., Kumari A., Patial V., et al., In situ functionalized nanobiocomposites dressings of bamboo cellulose nanocrystals and silver nanoparticles for accelerated wound healing. Carbohydrate Polymers, 2017, 155, 152-62.

30. Abdul Khalil H.P.S., Bhat A.H., Ireana Yusra A.F., Green composites from sustainable cellulose nanofibrils: A review. Carbohydrate Polymers, 2012, 87(2), 963-79.

31. Hamedi M., Karabulut E., Marais A., Herland A., Nyström G., Wågberg L., Nanocellulose Aerogels Functionalized by Rapid Layer-by-Layer Assembly for High Charge Storage and Beyond. Angewandte Chemie International Edition, 2013, 52(46), 12038-42.

32. Hubbe M.A., Venditti R.A., Rojas O.J., What happens to cellulosic fibers during papermaking and recycling? A review. BioResources, 2007, 2(4), 739-88.

33. Xu X., Synthesis of cellulose nanofiber composites for mechanical reinforcement and other advanced applications. 2015.

34. Arvidsson R., Nguyen D., Svanström M., Life cycle assessment of cellulose nanofibrils production by mechanical treatment and two different pretreatment processes. Environmental Science \& Technology, 2015, 49(11), 6881-90.

35. Hakalahti M., Mautner A., Johansson L.-S., Hänninen T., Setälä H., Kontturi E., et al., Direct interfacial modification of nanocellulose films for thermoresponsive membrane templates. ACS Applied Materials \& Interfaces, 2016, 8(5), 2923-7.

36. Moon R.J., Martini A., Nairn J., Simonsen J., Youngblood J., Cellulose nanomaterials review: structure, properties and nanocomposites. Chemical Society Reviews, 2011, 40(7), 3941-94.

37. Olsson C., Westman G., Direct dissolution of cellulose: background, means and applications. Cellulose-Fundamental Aspects: InTech, 2013.

38. Yang H.-S., Kiziltas A., Gardner D.J., Thermal analysis and crystallinity study of cellulose nanofibril-filled polypropylene composites. Journal of Thermal Analysis and Calorimetry, 2013, 1-10.
39. Teh P.F., Sharma Y., Pramana S.S., Srinivasan M., Nanoweb anodes composed of one-dimensional, high aspect ratio, size tunable electrospun $\mathrm{ZnFe} 204$ nanofibers for lithium ion batteries. Journal of Materials Chemistry, 2011, 21(38), 14999-5008.

40. Zhu J.Y., Sabo R., Luo X., Integrated production of nano-fibrillated cellulose and cellulosic biofuel (ethanol) by enzymatic fractionation of wood fibers. Green Chemistry, 2011, 13(5), 1339-44.

41. Wang Q.Q., Zhu J.Y., Reiner R.S., Verrill S.P., Baxa U., McNeil S.E., Approaching zero cellulose loss in cellulose nanocrystal (CNC) production: recovery and characterization of cellulosic solid residues (CSR) and CNC. Cellulose, 2012, 1-15.

42. Kalia S., Kaith B.S., Kaur I., Cellulose fibers: bio-and nano-polymer composites, green chemistry and technology. Springer Science \& Business Media, 2011.

43. Ng H.-M., Sin L.T., Tee T.-T., Bee S.-T., Hui D., Low C.-Y., et al., Extraction of cellulose nanocrystals from plant sources for application as reinforcing agent in polymers. Composites Part B: Engineering, 2015, 75, 176-200.

44. Jonoobi M., Oladi R., Davoudpour Y., Oksman K., Dufresne A., Hamzeh Y., et al., Different preparation methods and properties of nanostructured cellulose from various natural resources and residues: a review. Cellulose, 2015, 22(2).

45. Sandquist D., New horizons for microfibrillated cellulose. Appita Journal: Journal of the Technical Association of the Australian and New Zealand Pulp and Paper Industry, 2013, 66(2), 156.

46. Dufresne A., Nanocellulose: a new ageless bionanomaterial. Materials Today, 2013, 16(6), 220-7.

47. Kalashnikova I., Bizot H., Cathala B., Capron I., Modulation of cellulose nanocrystals amphiphilic properties to stabilize oil/water interface. Biomacromolecules, 2011, 13(1), 267-75.

48. Eichhorn S.J,, Dufresne A., Aranguren M., Marcovich N.E., Capadona J.R., Rowan S.J., et al., Current international research into cellulose nanofibres and nanocomposites. Journal of Materials Science, 2010, 45(1), 1-33.

49. Mohammadinejad R., Karimi S., Iravani S., Varma R.S., Plant-derived nanostructures: types and applications. Green Chemistry, 2016, 18(1), 20-52.

50. Trache D., Hussin M.H., Haafiz M.K.M., Thakur V.K., Recent progress in cellulose nanocrystals: sources and production. Nanoscale, 2017, 9(5), 1763-86.

51. Jack A.A., Nordli H.R., Powell L.C., Powell K.A., Kishnani H., Johnsen P.O., et al., The interaction of wood nanocellulose dressings and the wound pathogen P. aeruginosa. Carbohydrate Polymers, 2017, 157, 1955-62.

52. Štefelová J., Slovák V., Siqueira G., Olsson R.T., Tingaut P., Zimmermann T., et al., Drying and Pyrolysis of Cellulose Nanofibers from Wood, Bacteria, and Algae for Char Application in Oil Absorption and Dye Adsorption. ACS Sustainable Chemistry \& Engineering. 2017, 5(3), 2679-92.

53. Beck-Candanedo S., Roman M., Gray D.G., Effect of reaction conditions on the properties and behavior of wood cellulose nanocrystal suspensions. Biomacromolecules, 2005, 6(2), 1048-54.

54. Suopajärvi T., Liimatainen H., Karjalainen M., Upola H., Niinimäki J., Lead adsorption with sulfonated wheat pulp nanocelluloses. Journal of Water Process Engineering, 2015, 5, 136-42. 
55. Li M., Wang L.-J., Li D., Cheng Y.-L., Adhikari B., Preparation and characterization of cellulose nanofibers from de-pectinated sugar beet pulp. Carbohydrate Polymers, 2014, 102, 136-43.

56. Pacaphol K., Aht-Ong D., Preparation of hemp nanofibers from agricultural waste by mechanical defibrillation in water. Journal of Cleaner Production, 2017, 142, 1283-95.

57. Khiari R., Valorization of Agricultural Residues for Cellulose Nanofibrils Production and Their Use in Nanocomposite Manufacturing. International Journal of Polymer Science, 2017, 2017.

58. Morais J.P.S., de Freitas Rosa M., Nascimento L.D., do Nascimento D.M., Cassales A.R., Extraction and characterization of nanocellulose structures from raw cotton linter. Carbohydrate Polymers, 2013, 91(1), 229-35.

59. Rambabu N., Panthapulakkal S., Sain M., Dalai A.K., Production of nanocellulose fibers from pinecone biomass: evaluation and optimization of chemical and mechanical treatment conditions on mechanical properties of nanocellulose films. Industrial Crops and Products, 2016, 83, 746-54.

60. Cherpinski A., Torres-Giner S., Vartiainen J., Peresin M.S., Lahtinen P., Lagaron J.M., Improving the water resistance of nanocellulose-based films with polyhydroxyalkanoates processed by the electrospinning coating technique. Cellulose, 2018, 25(2), 1291-307.

61. Barbash V.A., Yaschenko O.V., Shniruk O.M., Preparation and properties of nanocellulose from Organosolv straw pulp. Nanoscale Research Letters, 2017, 12(1), 241.

62. Guimarães Junior M., Teixeira F.G., Tonoli G.H.D., Effect of the nano-fibrillation of bamboo pulp on the thermal, structural, mechanical and physical properties of nanocomposites based on starch/poly(vinyl alcohol) blend. Cellulose, 2018, 25(3), 1823-49.

63. Siqueira G., Bras J., Dufresne A., Cellulosic bionanocomposites: a review of preparation, properties and applications. Polymers, 2010, 2(4), 728-65.

64. Filson P.B., Dawson-Andoh B.E., Sono-chemical preparation of cellulose nanocrystals from lignocellulose derived materials. Bioresource Technology, 2009, 100(7), 2259-64.

65. Zhang Y., Cheng Q., Chang C., Zhang L., Phase transition identification of cellulose nanocrystal suspensions derived from various raw materials. Journal of Applied Polymer Science, 2017, 135(24), 45702.

66. Khalil H.P.S.A., Bhat A.H., Yusra A.F.I., Green composites from sustainable cellulose nanofibrils: A review. Carbohydrate Polymers, 2012, 87(2), 963-79.

67. Petersen N., Gatenholm P., Bacterial cellulose-based materials and medical devices: current state and perspectives. Applied Microbiology and Biotechnology, 2011, 91(5), 1277.

68. Rouabhia M., Asselin J.R.M., Tazi N., Messaddeq Y.S., Levinson D., Zhang Z., Production of biocompatible and antimicrobial bacterial cellulose polymers functionalized by RGDC grafting groups and gentamicin. ACS Applied Materials \& Interfaces, 2014, 6(3), 1439-46.

69. Alatalo S.-M., Pileidis F., Mäkilä E., Sevilla M., Repo E., Salonen J., et al., Versatile cellulose-based carbon aerogel for the removal of both cationic and anionic metal contaminants from water. ACS Applied Materials \& Interfaces, 2015, 7(46), 25875-83.

70. Foresti M.L., Vázquez A., Boury B., Applications of bacterial cellulose as precursor of carbon and composites with metal oxide, metal sulfide and metal nanoparticles: A review of recent advances. Carbohydrate Polymers, 2017, 157, 447-67.

71. Guo J., Catchmark J.M., Surface area and porosity of acid hydrolyzed cellulose nanowhiskers and cellulose produced by Gluconacetobacter xylinus. Carbohydrate Polymers, 2012, 87(2), 1026-37.

72. Charreau H., Foresti M., Vázquez A., Nanocellulose patents trends: a comprehensive review on patents on cellulose nanocrystals, microfibrillated and bacterial cellulose. Recent Patents on Nanotechnology, 2013, 7(1), 56-80.

73. Yang C., Gao C., Wan Y., Tang T., Zhang S., Dai K., Preparation and characterization of three-dimensional nanostructured macroporous bacterial cellulose/agarose scaffold for tissue engineering. Journal of Porous Materials, 2011, 18(5), 545-52.

74. Ruka D.R., Simon G.P., Dean K.M., Altering the growth conditions of Gluconacetobacter xylinus to maximize the yield of bacterial cellulose. Carbohydrate Polymers, 2012, 89(2), 613-22.

75. Jozala A.F., de Lencastre-Novaes L.C., Lopes A.M., de Carvalho Santos-Ebinuma V., Mazzola P.G., Pessoa-Jr A., et al., Bacterial nanocellulose production and application: a 10-year overview. Applied Microbiology and Biotechnology, 2016, 100(5), 2063-72.

76. Portela da Gama F.M., Bacterial NanoCellulose: what future? Bioimpacts, 2018, 8(1), 1-3.

77. Dayal M.S., Goswami N, Sahai A., Jain V., Mathur G., Mathur A., Effect of media components on cell growth and bacterial cellulose production from Acetobacter aceti MTCC 2623. Carbohydrate Polymers, 2013, 94(1), 12-6.

78. Vaidya R.J., Macmil S.L.A., Vyas P.R., Chhatpar H.S., The novel method for isolating chitinolytic bacteria and its application in screening for hyperchitinase producing mutant of Alcaligenes xylosoxydans. Letters in Applied Microbiology, 2003, 36(3), 129-34.

79. Klemm D., Schumann D., Udhardt U., Marsch S., Bacterial synthesized cellulose-artificial blood vessels for microsurgery. Progress in Polymer Science, 2001, 26(9), 1561-603.

80. Hungund B.S., Gupta S.G., Production of bacterial cellulose from Enterobacter amnigenus GH-1 isolated from rotten apple. World Journal of Microbiology and Biotechnology, 2010, 26(10), 1823-8.

81. Rezaei F., Xing D., Wagner R., Regan J.M., Richard T.L., Logan B.E., Simultaneous cellulose degradation and electricity production by Enterobacter cloacae in a microbial fuel cell. Applied and Environmental Microbiology. 2009, 75(11), 3673-8.

82. Grimm M., Stephan R., Iversen C., Manzardo G.G.G., Rattei T., Riedel K., et al., Cellulose as an extracellular matrix component present in Enterobacter sakazakii biofilms. Journal of Food Protection, 2008, 71(1), 13-8.

83. Chen X., Wang Y., Yang F., Qu Y., Li X., Isolation and characterization of Achromobacter sp. CX2 from symbiotic Cytophagales, a non-cellulolytic bacterium showing synergism with cellulolytic microbes by producing $\beta$-glucosidase. Annals of Microbiology, 2015, 65(3), 1699-707.

84. Gjermansen M., Nilsson M., Yang L., Tolker-Nielsen T., Characterization of starvation-induced dispersion in Pseudomonas putida biofilms: genetic elements and molecular mechanisms. Molecular Microbiology, 2010, 75(4), 815-26.

85. Spiers A.J., Bohannon J., Gehrig S.M., Rainey P.B., Biofilm formation at the air-liquid interface by the Pseudomonas fluorescens SBW25 wrinkly spreader requires an acetylated form of cellulose. Molecular Microbiology, 2003, 50(1), 15-27. 
86. Robledo M., Rivera L., Jiménez-Zurdo J.I., Rivas R., Dazzo F., Velázquez E., et al., Role of Rhizobium endoglucanase CelC2 in cellulose biosynthesis and biofilm formation on plant roots and abiotic surfaces. Microbial Cell Factories, 2012, 11(1), 125.

87. Römling U., Galperin M.Y., Bacterial cellulose biosynthesis: diversity of operons, subunits, products, and functions. Trends in Microbiology, 2015, 23(9), 545-57.

88. Solano C., García B., Valle J., Berasain C., Ghigo J.M., Gamazo C., et al., Genetic analysis of Salmonella enteritidis biofilm formation: critical role of cellulose. Molecular Microbiology, 2002, 43(3), 793-808.

89. Mihranyan A., Cellulose from cladophorales green algae: From environmental problem to high-tech composite materials. Journal of Applied Polymer Science,2010, 119(4), 2449-60.

90. Chen Y.W., Lee H.V., Juan J.C., Phang S.-M., Production of new cellulose nanomaterial from red algae marine biomass Gelidium elegans. Carbohydrate Polymers, 2016, 151, 1210-9.

91. Singh S., Gaikwad K.K., Park S.-I., Lee Y.S., Microwave-assisted step reduced extraction of seaweed (Gelidiella aceroso) cellulose nanocrystals. International Journal of Biological Macromolecules. 2017, 99, 506-10.

92. Habibi Y., Lucia L.A., Rojas O.J., Cellulose Nanocrystals: Chemistry, Self-Assembly, and Applications. Chemical Reviews, 2010, 110(6), 3479-500.

93. Yang S., Xie Q., Liu X., Wu M., Wang S., Song X., Acetylation improves thermal stability and transmittance in FOLED substrates based on nanocellulose films. RSC Advances, 2018, 8(7), 3619-25.

94. Gan L., Liao J., Lin N., Hu C., Wang H., Huang J., Focus on Gradientwise Control of the Surface Acetylation of Cellulose Nanocrystals to Optimize Mechanical Reinforcement for Hydrophobic Polyester-Based Nanocomposites. ACS Omega, 2017, 2(8), 4725-36.

95. Chaker A., Boufi S., Cationic nanofibrillar cellulose with high antibacterial properties. Carbohydr Polym., 2015, 131, 224-32. PubMed PMID: 26256179.

96. Hassanpour A., Asghari S., Lakouraj M.M., Mohseni M., Preparation and characterization of contact active antibacterial surface based on chemically modified nanofibrillated cellulose by phenanthridinium silane salt. International Journal of Biological Macromolecules, 2018, PubMed PMID: 29581000.

97. Dong S., Roman M., Fluorescently Labeled Cellulose Nanocrystals for Bioimaging Applications. Journal of the American Chemical Society, 2007, 129(45), 13810-1.

98. Wiegand C., Moritz S., Hessler N., Kralisch D., Wesarg F., Muller F.A., et al., Antimicrobial functionalization of bacterial nanocellulose by loading with polihexanide and povidoneiodine. Journal of Materials Science Materials in Medicine. 2015, 26(10), 245, PubMed PMID: 26411441.

99. Taran M., Rad M., Alavi M., Characterization of Ag nanoparticles biosynthesized by Bacillus sp. HAI4 in different conditions and their antibacterial effects. Journal of Applied Pharmaceutical Science, 2016, 6(11), 094-9.

100. TQasim M., Udomluck N., Chang J., Park H., Kim K., Antimicrobial activity of silver nanoparticles encapsulated in poly- $\mathrm{N}$-isopropylacrylamide-based polymeric nanoparticles. International Journal of Nanomedicine, 2018, 13, 235-49. PubMed PMID: PMC5757205.

101. Acharya D., Singha K.M., Pandey P., Mohanta B., Rajkumari J., Singha L.P., Shape dependent physical mutilation and lethal effects of silver nanoparticles on bacteria. Scientific Reports, 2018, 8(1), 201.

102. Osibe D.A., Chiejina N.V., Ogawa K., Aoyagi H., Stable antibacterial silver nanoparticles produced with seed-derived callus extract of Catharanthus roseus. Artificial Cells, Nanomedicine, and Biotechnology, 2017, 1-8.

103. Alavi M., Karimi N., Antiplanktonic, antibiofilm, antiswarming motility and antiquorum sensing activities of green synthesized $\mathrm{Ag}-\mathrm{TiO}_{2}, \mathrm{TiO}_{2}-\mathrm{Ag}, \mathrm{Ag}-\mathrm{Cu}$ and $\mathrm{Cu}-\mathrm{Ag}$ nanocomposites against multi-drug-resistant bacteria. Artificial Cells, Nanomedicine, and Biotechnology, 2018, 1-15.

104. Rai M.K., Deshmukh S.D., Ingle A.P., Gade A.K., Silver nanoparticles: the powerful nanoweapon against multidrugresistant bacteria. Journal of Applied Microbiology, 2012, 112(5), 841-52.

105. El-Zahry M.R., Mahmoud A., Refaat I.H., Mohamed H.A., Bohlmann H., Lendl B., Antibacterial effect of various shapes of silver nanoparticles monitored by SERS. Talanta, 2015, 138, 183-9.

106. Panáček A., Kolář M., Večeřová R., Prucek R., Soukupová J., Kryštof V., et al., Antifungal activity of silver nanoparticles against Candida spp. Biomaterials, 2009, 30(31), 6333-40.

107. Zhang X.-F., Liu Z.-G., Shen W., Gurunathan S., Silver nanoparticles: synthesis, characterization, properties, applications, and therapeutic approaches. International Journal of Molecular Sciences, 2016, 17(9), 1534.

108. Lara H.H., Ayala-Nuñez N.V., Ixtepan-Turrent L., RodriguezPadilla C., Mode of antiviral action of silver nanoparticles against HIV-1. Journal of Nanobiotechnology, 2010, 8(1), 1.

109. Kulpinski P., Bioactive cellulose fibres with silver nanoparticles. e-Polymers, 2007, 7(1).

110. Wu J., Zheng Y., Song W., Luan J., Wen X., Wu Z., et al., In situ synthesis of silver-nanoparticles/bacterial cellulose composites for slow-released antimicrobial wound dressing. Carbohydrate Polymers, 2014, 102, 762-71.

111. Berndt S., Wesarg F., Wiegand C., Kralisch D., Müller F.A., Antimicrobial porous hybrids consisting of bacterial nanocellulose and silver nanoparticles. Cellulose, 2013, 20(2), 771-83.

112. Nguyen H.-L., Jo Y.K., Cha M., Cha Y.J., Yoon D.K., Sanandiya N.D., et al., Mussel-inspired anisotropic nanocellulose and silver nanoparticle composite with improved mechanical properties, electrical conductivity and antibacterial activity. Polymers, 2016, 8(3), 102.

113. Taran M., Rad M., Alavi M., Biological synthesis of copper nanoparticles by using Halomonas elongata IBRC-M 10214/ Sinteza biologica a nanoparticulelor de cupru prin utilizarea Halomonas elongata IBRC-M 10214. Industria Textila, 2016, 67(5), 351.

114. Taran M., Rad M., Alavi M., Antibacterial Activity of Copper Oxide (CuO) Nanoparticles Biosynthesized by Bacillus sp. FU4: Optimization of Experiment Design, 2017.

115. Tapiero H., Townsend D.M., Tew K.D., Trace elements in human physiology and pathology. Copper. Biomedicine \& Pharmacotherapy, 2003, 57(9), 386-98.

116. Jia B., Mei Y., Cheng L., Zhou J., Zhang L., Preparation of copper nanoparticles coated cellulose films with antibacterial properties through one-step reduction. ACS Applied Materials \& Interfaces, 2012, 4(6), 2897-902.

117. Mary G., Bajpai S.K., Chand N., Copper (II) ions and copper nanoparticles-loaded chemically modified cotton cellulose 
fibers with fair antibacterial properties. Journal of Applied Polymer Science, 2009, 113(2), 757-66.

118. Cady N.C., Behnke J.L., Strickland A.D., Copper-Based Nanostructured Coatings on Natural Cellulose: Nanocomposites Exhibiting Rapid and Efficient Inhibition of a Multi-Drug Resistant Wound Pathogen, A. baumannii, and Mammalian Cell Biocompatibility In Vitro. Advanced Functional Materials, 2011, 21(13), 2506-14.

119. Pinto R.J.B., Daina S., Sadocco P., Neto C.P., Trindade T., Antibacterial activity of nanocomposites of copper and cellulose. BioMed Research International, 2013.

120. Emam H.E., Manian A.P., Široká B., Duelli H., Merschak P., Redl B., et al., Copper(I)oxide surface modified cellulose fibersSynthesis, characterization and antimicrobial properties. Surface and Coatings Technology, 2014, 254, 344-51.

121. Ghule K., Ghule A.V., Chen B.-J., Ling Y.-C., Preparation and characterization of $\mathrm{ZnO}$ nanoparticles coated paper and its antibacterial activity study. Green Chemistry, 2006, 8(12), 1034-41.

122. Oliveira J.A., Nogueira A.E., Gonçalves M.C.P., Paris E.C., Ribeiro C., Poirier G.Y., et al., Photoactivity of N-doped ZnO nanoparticles in oxidative and reductive reactions. Applied Surface Science, 2018, 433, 879-86.

123. Tripathi D.K., Shweta, Singh S., Singh S., Pandey R., Singh V.P., et al., An overview on manufactured nanoparticles in plants: Uptake, translocation, accumulation and phytotoxicity. Plant Physiology and Biochemistry, 2017 110, 2-12.

124. Martins N.C.T., Freire C.S.R., Neto C.P., Silvestre A.J.D., Causio J., Baldi G., et al., Antibacterial paper based on composite coatings of nanofibrillated cellulose and $\mathrm{ZnO}$. Colloids and Surfaces A: Physicochemical and Engineering Aspects. 2013, 417, 111-9.

125. Azizi S., Ahmad B.M., Hussein Z.M., Ibrahim A.N., Synthesis, Antibacterial and Thermal Studies of Cellulose Nanocrystal Stabilized ZnO-Ag Heterostructure Nanoparticles. Molecules (Basel, Switzerland), 2013, 18(6).

126. Fu F., Li L., Liu L., Cai J., Zhang Y., Zhou J., et al., Construction of Cellulose Based ZnO Nanocomposite Films with Antibacterial Properties through One-Step Coagulation. ACS Applied Materials \& Interfaces, 2015, 7(4), 2597-606.

127. Shahmohammadi Jebel F., Almasi H., Morphological, physical, antimicrobial and release properties of $\mathrm{ZnO}$ nanoparticlesloaded bacterial cellulose films. Carbohydrate Polymers, 2016, 149, 8-19.

128. Khalid A., Khan R., Ul-Islam M., Khan T., Wahid F., Bacterial cellulose-zinc oxide nanocomposites as a novel dressing system for burn wounds. Carbohydrate Polymers, 2017, 164, 214-21.

129. Cargnello M., Gordon T.R., Murray C.B., Solution-Phase Synthesis of Titanium Dioxide Nanoparticles and Nanocrystals. Chemical Reviews, 2014, 114(19), 9319-45.

130. Bakhsheshi-Rad H.R., Hamzah E., Staiger M.P., Dias G.J., Hadisi Z., Saheban M., et al., Drug release, cytocompatibility, bioactivity, and antibacterial activity of doxycycline loaded Mg-Ca-TiO2 composite scaffold. Materials \& Design, 2018, 139, 212-21.

131. Viet P.V., Phan B.T., Mott D., Maenosono S., Sang T.T., Thi C.M., et al., Silver nanoparticle loaded $\mathrm{TiO} 2$ nanotubes with high photocatalytic and antibacterial activity synthesized by photoreduction method. Journal of Photochemistry and Photobiology A: Chemistry, 2018, 352, 106-12.
132. Xiao W., Xu J., Liu X., Hu Q., Huang J., Antibacterial hybrid materials fabricated by nanocoating of microfibril bundles of cellulose substance with titania/chitosan/silver-nanoparticle composite films. Journal of Materials Chemistry B, 2013, 1(28), 3477-85.

133. Khan S., Ul-Islam M., Khattak W.A., Ullah M.W., Park J.K., Bacterial cellulose-titanium dioxide nanocomposites: nanostructural characteristics, antibacterial mechanism, and biocompatibility. Cellulose, 2015, 22(1), 565-79.

134. Khafaga M.R., Ali H.E., El-Naggar A.W.M., Antimicrobial finishing of cotton fabrics based on gamma irradiated carboxymethyl cellulose/poly(vinyl alcohol)/TiO2 nanocomposites. The Journal of The Textile Institute, 2016, 107(6), 766-73.

135. Jebali A., Hekmatimoghaddam S., Behzadi A., Rezapor I., Mohammadi B.H., Jasemizad T., et al., Antimicrobial activity of nanocellulose conjugated with allicin and lysozyme. Cellulose, 2013, 20(6), 2897-907.

136. Moritz S., Wiegand C., Wesarg F., Hessler N., Müller F.A., Kralisch D., et al., Active wound dressings based on bacterial nanocellulose as drug delivery system for octenidine. International Journal of Pharmaceutics, 2014, 471(1), 45-55.

137. Dehnad D., Mirzaei H., Emam-Djomeh Z., Jafari S.-M., Dadashi S., Thermal and antimicrobial properties of chitosan-nanocellulose films for extending shelf life of ground meat. Carbohydrate Polymers, 2014, 109, 148-54.

138. Wiegand C., Moritz S., Hessler N., Kralisch D., Wesarg F., Müller F.A., et al., Antimicrobial functionalization of bacterial nanocellulose by loading with polihexanide and povidoneiodine. Journal of Materials Science: Materials in Medicine, 2015, 26(10), 245.

139. Sampaio L.M.P., Padrão J., Faria J., Silva J.P., Silva C.J., Dourado F., et al., Laccase immobilization on bacterial nanocellulose membranes: Antimicrobial, kinetic and stability properties. Carbohydrate Polymers, 2016, 145, 1-12.

140. Kamoun E.A., Kenawy E.-R.S., Chen X., A review on polymeric hydrogel membranes for wound dressing applications: PVA-based hydrogel dressings. Journal of Advanced Research, 2017, 8(3), 217-33.

141. Mostafalu P., Tamayol A., Rahimi R., Ochoa M., Khalilpour A., Kiaee G., et al., Smart Bandage for Monitoring and Treatment of Chronic Wounds. Small, 2018, 14(33), 1703509.

142. Lin S.-P., Kung H.-N., Tsai Y.-S., Tseng T.-N., Hsu K.-D., Cheng K.-C., Novel dextran modified bacterial cellulose hydrogel accelerating cutaneous wound healing. Cellulose, 2017, 24(11), 4927-37.

143. Laçin N.T., Development of biodegradable antibacterial cellulose based hydrogel membranes for wound healing. International Journal of Biological Macromolecules, 2014, 67, 22-7.

144. Serra R., Grande R., Butrico L., Rossi A., Settimio U.F., Caroleo B., et al., Chronic wound infections: the role of Pseudomonas aeruginosa and Staphylococcus aureus. Expert Review of Anti-Infective Therapy, 2015, 13(5), 605-13.

145. Sulaeva I., Henniges U., Rosenau T., Potthast A., Bacterial cellulose as a material for wound treatment: Properties and modifications. A review. Biotechnology Advances, 2015, 33(8), 1547-71.

146. Lu T., Li Q., Chen W., Yu H., Composite aerogels based on dialdehyde nanocellulose and collagen for potential applications as wound dressing and tissue engineering scaffold. Composites Science and Technology, 2014, 94, 132-8. 
147. Rees A., Powell L.C., Chinga-Carrasco G., Gethin D.T., Syverud K., Hill K.E., et al., 3D bioprinting of carboxymethylated-periodate oxidized nanocellulose constructs for wound dressing applications. BioMed Research International, 2015.

148. Naseri N., Mathew A.P., Girandon L., Fröhlich M., Oksman K., Porous electrospun nanocomposite mats based on chitosan- cellulose nanocrystals for wound dressing: effect of surface characteristics of nanocrystals. Cellulose, 2015, 22(1), 521-34.

149. Liu J., Chinga-Carrasco G., Cheng F., Xu W., Willför S., Syverud K., et al., Hemicellulose-reinforced nanocellulose hydrogels for wound healing application. Cellulose, 2016, 23(5), 3129-43. 